Article

\title{
Financial Structure and Financing Constraints: Evidence on Small- and Medium-Sized Enterprises in China
}

\author{
Sumei Luo ${ }^{1}$, Yuxi Zhang ${ }^{2}$ and Guangyou Zhou ${ }^{2, *}$ \\ 1 School of Finance, Shanghai University of Finance and Economics, Shanghai 200433, China; \\ luosumei@shufe.edu.cn \\ 2 School of Economics, Fudan University, Shanghai 200433, China; 17210680175@fudan.edu.cn \\ * Correspondence: zgy@fudan.edu.cn
}

Received: 26 April 2018; Accepted: 24 May 2018; Published: 29 May 2018

\begin{abstract}
The difficulty of financing for small- and medium-sized enterprises is an important problem that has plagued China's economic development for a long time, so it is of great practical significance to explore how to solve the problem of financing difficulties for small- and medium-sized enterprises. From the perspective of financial structure, this paper introduces it to the analytical framework of the investment-cash flow sensitivity model, and establishes a two-way fixed effect model on the basis of the financial structure and other external financing conditions, so as to study the impact of the financial structure in China, especially the banking structure, on the financing constraints of smalland medium-sized enterprises. At the same time, the data of 161 listed companies on the Small and Medium Enterprise Board from 2009 to 2013 is used to carry out an empirical test on the correlation between the financial structure factors and the financing constraints of small- and medium-sized enterprises. The study shows that the promotion of the scale ratio of small- and medium-sized enterprises in the banking industry is able to significantly alleviate the financing constraints of smalland medium-sized enterprises. Meanwhile, the structure of the banking industry should adapt to the industrial structure, in order to achieve the sustained and stable development of the real economy.
\end{abstract}

Keywords: SME financing; financial structure; small- and medium-sized banks; sustainable development

\section{Introduction}

At the present stage, the downward pressure of China's economy has increased. In 2017, GDP grew by $6.9 \%$ over the same period last year, and the growth rate of GDP has been less than $7 \%$ in the past three years. Moreover, the lack of macroeconomic prosperity also makes it weak in consumption and investment. In addition, since the first quarter of 2018, the scale of net exports has begun to shrink, and the driving force of the economy has further declined. According to the National Small and Micro enterprises Development report issued by the State Administration of Industry and Commerce in 2014, small- and medium-sized enterprises contribute more than $60 \%$ of the GDP, provide more than $80 \%$ of employment post for cities and towns, contribute more than $50 \%$ of tax revenue to finance, and contribute more to economic development than large state-owned enterprises. As the main force of Chinese economic development, small- and medium-sized enterprises, on the one hand, have relatively dense labor and flexible operating mechanism to make them have comparative advantages, which can better adapt to the characteristics of Chinese industry and promote economic growth. On the other hand, small- and medium-sized enterprises have more advantages than large state-owned enterprises in innovation. In recent years, many high-tech enterprises have emerged and they are innovating in e-commerce, shared travel, artificial intelligence, blockchain technology, 
and business models. These innovations are a source of impetus for economic growth. They can also promote employment, consumption and educational progress, so they are contributing to a positive feedback effect. This ensures that Chinese economy continues to grow steadily in the long run. Therefore, to promote the development of small- and medium-sized investment is an important topic of economic growth. In this context, how to grasp the direction of financial reform and promote sustainable economic growth has attracted wide concerns. As the main force of China's economic growth, small- and medium-sized enterprises are characterized by the relatively intense labor force and a flexible operating mechanism, which allows these enterprises to have certain comparative advantages. As a result, promoting the investment of small- and medium-sized enterprises is an important issue to promote economic development. However, there is a great demand for financing of small- and medium-sized enterprises, which is out of line with the less actual investment, and the unreasonable allocation of financial resources makes the financing difficulty of small- and medium-sized enterprises become a bottleneck problem. Under the background of declining growth of economic aggregate and low demand for investment, it has become an urgent problem to be solved in the present financial reform to find proper ways to realize the optimal allocation of financial resources and to improve the difficult situation of financing for small- and medium-sized enterprises so as to play the "long tail effect".

What is the direction of financial reform to solve the financing constraints of small- and medium-sized enterprises? The central bank requires the state-owned banks to increase loans to small- and medium-sized enterprises and to raise the floating range for the interest rate of their loans, which not only has little effect, but also leads to the intensification of financial risks. Moreover, it is not in line with the endogenous principle of specialized division of labor within the credit market. In terms of the financing difficulties of small- and medium-sized enterprises, on the one hand, it is determined by the internal conditions, such as the mortgage assets, the individual capacity of the operators, and the nature of the industry. On the other hand, it is also related to the external conditions, that is, the capital supply of the banks and other financial institutions. The external conditions involve the development level of the financial market, the structural arrangement of the financial system, and the price mechanism of the interest rate adjustment, in which the structural arrangement of the financial system directly determines the availability of the financing of the small- and medium-sized enterprises. As a developing country, the financial system in China is dominated by the banking industry. The big banks tend to pay attention to "hard" information of the financing enterprises, such as the financial statements and mortgaged assets, while they have less knowledge of the credit conditions of small- and medium-sized enterprises. On the contrary, the small- and medium-sized banks are mostly local financial institutions, and the long-term partnership has enabled them to have a better understanding of the individualized information of small- and medium-sized enterprises, and it is low in the information asymmetry between banks and enterprises. Therefore, the financial resources of small- and medium-sized banks are extremely important for small- and medium-sized enterprises with opaque information.

From the perspective of the financial structure, this paper will take the banking structure as the representative to study the impact of the status of small- and medium-sized banks in the banking industry on the financing of small- and medium-sized enterprises. At the same time, the paper uses the data of 161 companies on the Small and Medium Enterprise Board from 2009 to 2013 to carry out an empirical test to identify whether the small- and medium-sized enterprise have financing constraints, and whether the promotion of the scale ratio of small- and medium-sized banks is able to alleviate the financing constraints. And then, based on the analysis of the test results, this paper puts forward some policy proposals for financial reform.

The difference between this paper and the existing research lies in the following aspects. First, this paper studies the financing problem of small- and medium-sized enterprises from the perspective of financial structure, so that the research perspective is relatively novel. Second, when discussing the financial structure factors, we introduce the internal structure of the banking industry, the scale 
ratio of banking to stock market and other factors to carry out a comprehensive analysis. Third, the investment-cash flow sensitivity model is introduced and the empirical research is conducted on 161 companies on the SME Board from 2009 to 2013, which will make up for the shortcomings of the existing research to a certain extent. Fourth, on the basis of the theory of information asymmetry, this paper puts forward that the specialized division of labor in the banking industry will help to form the optimal financial structure and then adapt to the labor-intensive industrial structure in China.

The remaining part of this paper is composed of the following:

Second Section: It is the literature review, which briefly introduces the related research on financing constraints of small- and medium-sized enterprises in recent years.

Third Section: It is the theoretical analysis and the setting of a measurement model.

Fourth Section: It is the data explanation and the empirical test, in which the results of measurement are sorted out and analyzed.

Fifth Section: It is the conclusions and suggestions to reveal the practical significance of the empirical test, and to put forward some policy suggestions for the current financial reform.

\section{Literature Review and Theoretical Hypothesis}

\subsection{Literature Review}

The importance of financing problems of small- and medium-sized enterprises stems from its linkage with economic growth and industrial cycle. The financing of small- and medium-sized enterprises has obvious economic effect. Al-Zoubi and Jennifer A. (2018) [1] believed that the capital structure of an enterprise has the same cyclical characteristics as the macro-economy, and the capital structure has a certain sustainability. This is because the macroeconomic boom or recession determines the periodicity and sustainability of enterprise income, thus affecting the financing mode and capital structure of enterprises. The capital structure arrangement of the enterprise will affect the leverage ratio of the real economy, thus affecting the macroeconomic cycle. John, Mark, and Michaeler (2015) [2] argued that in the context of a stable economy and a loosely regulated industry, corporate leverage ratio is increasing. This situation also affects the financing and capital structure of small- and medium-sized enterprises. These scholars also studied the economic development and enterprise financing in the 20th century from the perspective of historical development. Davide Castellani (2018) [3] studied the relationship between small- and medium-sized enterprise lending and MBS(Mortgage-Backed Security) during the 2007-2014 economic and financial crisis. He believes that the economic crisis has frozen liquidity, increased lending risk and reduced liquidity in bank lending to small- and medium-sized enterprises, thus boosting the development of MBS represented by home mortgages. Meanwhile, data from the banking industry in Italy also support this view.

And the study of Zarutskie (2013) [4] Farruggio and Uhde (2015) [5] shows that the macroeconomic and industry environment has a significant impact on bank lending, and that banks of different sizes have different preferences for lending to enterprises in a better economic environment. In turn, big banks tend to do more MBS, while smaller banks tend to do the opposite. Hoffmann and Sorensen (2015) [6] studied the relationship between the independence of local banks in the euro area and the financing of small- and medium-sized enterprises, as well as their impact on the real economy. They concluded that small- and medium-sized enterprises are highly dependent on local bank financing and this dependency makes small- and medium-sized enterprises more vulnerable to the banking crisis, which in turn has a major impact on the real sector. Almazan, Motta, and Titmang (2015) [7], Chodorow-Reichn (2014) [8], Fogel, Morck, and Yeungsu (2008) [9] also studied the relationship between small- and medium-sized enterprise financing, bank lending and labour market and economic growth.

At the same time, the current situation of financing difficulty of small and medium-sized enterprises is common in all countries around the world, and scholars at home and abroad have done a lot of related researches to analyze their financing constraints and the underlying influence 
factors. Since Myers (1984) [10] and (1993) [11] studied corporate financing and capital structure in the early years, the discussion on this issue has never been interrupted. The pecking order theory and the static tradeoff theory are the theoretical foundation of explaining the financing decision of enterprises. When it comes to the problem of small- and medium-sized enterprises, its explanatory power is not satisfactory.

The financing constraint of the small- and medium-sized enterprises is a common problem encountered by various countries at different stages of development. In recent years, the research on the causes and solutions of financing difficulties of small- and medium-sized enterprises has been constantly emerging, which mainly focuses on the internal factors of the enterprises, financial liberalization, financial structure optimization and interest rate marketization, and other aspects.

In terms of internal factors, the internal factors affecting the financing difficulties of Small and Micro enterprises include cash holdings, enterprise size, enterprise growth cycle, ownership nature, corporate governance, and so on. As far as the internal factors of the enterprise are concerned, the internal factors that affect the financing difficulties of small- and medium-sized enterprises include the cash holdings, the scale of the enterprise, and the growth cycle of the enterprise and the nature of ownership. First, companies with higher financing constraints tend to increase their cash holdings to avoid missing good investment opportunities, while companies without financing constraints do not have such a phenomenon (Jiang Long, Liu Xiaosong, 2011) [12]. Some scholars believe that enterprises hold more cash for preventive motives, and it will be conducive to the improvement of enterprise value (Zhang Huili, Lu Zhengfei, 2012) [13], Winifred, Mazouz (2018) [14]. Second, without regard for the risk of investment projects, the larger the scale of enterprises is, the smaller the financing constraints will be (Cole, 2013) [15]. Cai Jian, Sun Dan, and Li Hongjin (2015) [16] believe that the level of financing constraints of large enterprises is lower than that of small and micro enterprises, and an empirical test was carried out based on the data of the enterprises in Beijing. Third, the theory of the enterprise growth cycle takes into account the different stages of development and the corresponding financing characteristics of the enterprise, as well as studies the enterprise financing mode from a dynamic point of view. Hadlock C.J. and Pierce J.R. (2010) [17] their study also shows that the size of the enterprise is the main reason for the financing constraints of Small and Micro enterprises. Ylhäinen (2017) [18] studied the relationship between the financing cost and the life cycle of small- and medium-sized enterprises. He first divided the growth cycle of enterprises into four stages, that is, initial stage, growth period, maturity stage and recession stage, and it is found that the enterprise has a higher financing cost at the initial stage and growth stage, which means that there are certain financing constraints. Because of the lack of the venture capital and the mortgaged assets in the initial stage, the foreign financing is restricted, and the enterprise may encounter a narrow range of financing channels, so that it is difficult to finance through the open market. Finally, the nature of ownership also affects the difficulty of financing. Kieschnick and Moussa wiki (2018) [19] argued that enterprise life cycle and corporate governance affect both financing and capital structure, and that the better corporate governance is, the higher the debt financing ratio increases as its years grow. Because better corporate governance creates conditions for companies to commit to riskier capital structure decisions. Hasan and Cheungli (2018) [20] and other scholars have also done research on enterprise life cycle and capital structure.

Qaiser Munir, Sook Ching Kok, Tamara Teplova, and Tongxia Li (2017) [21] believed that enterprises with large management power are prone to principal-agent problems, and their exogenous financing often faces constraints, and showed that the debt rate of some enterprises with large management power is low or close to zero. It is not due to the difficulty of exogenous financing, but because of the strong profitability and sufficient funds, the tendency of exogenous financing is small. The research of Takashi Shibata and Michi Nishihara (2018) [22] showed that the limits on corporate debt issuance would reduce leverage and default risk, but it would not trigger financial constraints and would not affect investment activity. In addition, from the perspective of the nature of equity. In addition, from the perspective of the nature of equity, Poncet, Steingress, 
and Vandenbussche (2010) [23] believe that private enterprises are facing significant financing constraints, while state-owned enterprises and foreign enterprises do not encounter such a problem, and an empirical test was carried out based on the data of 4264 listed companies in China from 1998 to 2005. The research of Yan Dong and Chao Men (2014) [24] also shows that the nature of the enterprise equity has a significant impact on its financing. Compared with the state-owned enterprises, it is more difficult for the private enterprises to finance. Martellini, Milhau, and Tarelli (2018) [25] have also quantitatively studied the influence factors of financing constraints and optimal debt ratio.

In terms of interest rate marketization, in the period of China's economic transformation, it is particularly important to promote the marketization of interest rates and to build an institutional environment which is conducive to fair competition so as to optimize the credit resources and alleviate financing constraints. In order to stimulate investment, some developing countries which are similar to China have artificially lowered their interest rates, which will result in the excessive investment and the problems in credit rationing and enterprise financing constraints, so that it will make the allocation of funds inefficient and go against the economic growth. Therefore, the marketization of interest rates is able to improve the efficiency of capital allocation. Wang Dongjing and Zhang Xiangjian (2007) [26] believe that the loan interest rate rises after easing the government's control of interest rates, which will increase the financing cost of the enterprise, and restrain the excessive capital demand of the enterprise, so that it will alleviate the problem of credit rationing. The research of Ranciere R., Tornell A., and Westermann F. (2006) [27] shows that interest rate marketization will be beneficial to the financing and economic growth of the small- and medium-sized enterprises. Li Cheng, Huang Youxi, and Li Yuliang (2014) [24] hold that interest rate marketization is able to improve the financing difficulty of non-state-owned enterprises, to help to reduce the gap in the return on loans between the state-owned enterprises and non-state-owned enterprises, and to improve the loan incentives of banks to the non-state economy, and they adopted the panel data of 39 industries from 2002 to 2011 to test the correctness of the theory. Fuxiu J., Zhan J., and Kenneth A.K. (2017) [28] show in their study that the interest rate liberalization policy in China can reduce the financing cost of enterprises and promote the investment activities of small- and medium-sized enterprises. And the research of Li Dong, et al. (2017) [29] indicates that the loans of commercial banks go to more large enterprises rather than small- and medium-sized enterprises in the process of China's interest rate marketization, so that the interest rate marketization cannot effectively solve the financing difficulties for small- and medium-sized enterprises.

In terms of financial liberalization, the level of development of the financial system also affects the financing of small- and medium-sized enterprises. The expansion of the financial market in scale provides a more perfect capital circulation market, and realizes the equilibrium of capital supply and demand spontaneously through the adjustment of capital prices. Tang Jianxin and Chen Dong (2009) [30] believe that financial development is able to significantly alleviate the financing constraints of small- and medium-sized enterprises, and such a mitigation effect comes from the marketization of credit fund distribution and the introduction of foreign capital into the financial market, and they have proved it in accordance with the data of the SME Board in China from 2005 to 2007. Brown, Martinsson, and Petersen (2012) [31] believe that the development of equity financing and capital market liberalization is able to lead the enterprise in innovation, thus promoting enterprise financing and economic growth, and they also carried out an empirical test based on the data from some European companies. Schans (2015) [32] believes that the expansion of the financial market in level is able to provide more financing for small- and medium-sized enterprises, and then to promote economic growth, and he presented the empirical support through the data from the UK. Zhang and Rongda Chen (2014) [33] studied the influence of the financial repression in China on the financing constraints of small and medium enterprises, and carried out an empirical test based on the GMM (Generalized method of moments) method. They made a conclusion that the financial repression hinders the financing of small- and medium-sized enterprises, and proposed that the construction of a multi-level capital market is an effective way to solve the financing problems of small- and 
medium-sized enterprises. The study of Li Jianjun and Hu Fengyun (2013) [34] also explained that the development of the shadow credit market has derived a large number of securitized assets, and the financial innovation has reduced the financing cost of small- and medium-sized enterprises and alleviated the financing constraints. In addition, the development of supply chain finance is able to make up for the credit absence of small- and medium-sized enterprises as well as to reduce the information asymmetry of the credit market. The research of Feng X., Moon I., and Ryu K. (2015) [35] reflects that the small- and medium-sized enterprises in the supply chain can reduce the cost of funds through the income sharing contract and the repurchase contract and other means so as to alleviate the financing constraints they face. But some scholars, such as Santiago C., Francisco, and Gregory (2016) [36] argued that small- and medium-sized enterprises do not necessarily need to finance themselves through financial institutions such as banks, and that they can get money through trade credits. This phenomenon was particularly evident during the financial crisis.

In terms of financial structure optimization, the internal structure of financial system also affects the financing efficiency of the small- and medium-sized enterprises, on which there are great differences between scholars at home and abroad. Leon (2015) [37] believes that reasonable competition in the banking industry can not only improve the efficiency of capital allocation in the banking industry, alleviate the problems in financing constraints of enterprises, but also increase the motivation of enterprise financing from the banks, and he has carried out an empirical analysis on the basis of the enterprise panel data from 69 developing countries and regions. Love and Peria (2015) [38] studied from another point of view and found that the lower the internal competition of the banking industry is, the greater the hindrance to the enterprise financing will be, and this process is affected by the credit information sharing mechanism. Robert, Conor, and Fergal (2014) [39] and Demirg-Kunt A., Feyen E., and Levine R. (2013) [40] focused on the small and medium sized enterprises in developed countries and believe that the market power of the banking industry is able to effectively alleviate the financing constraints of small- and medium-sized enterprises. Mercieca, Schaeck, and Wolfe (2009) [41] studied the banking structure in Europe and found that the enhancement of the fierce competition in the banking industry will be able to increase the financing of small- and medium-sized enterprises, and the enhancement of the concentration of the banking industry will be able to reduce the financing of small- and medium-sized enterprises. Chong T.L., Lu 1., and Ongena S. (2013) [42]. They have studied the problems in China and believe that moderate competition in the banking sector can alleviate the financing constraints of Small and Micro enterprises. On the basis of the efficiency of the financial system to serve the real economy, Quaye, Abrokwah, Sarbah, and Osel (2014) [43] hold that the development of small and micro financial institutions will help to make up for the financing gap of small- and medium-sized enterprises. Berger and Black (2010) [44] believe that small- and medium-sized banks have comparative advantages with regard to information production and lending strategies, so that they are able to alleviate the financing constraints of small- and medium-sized enterprises in an effective way. On the information production capacity, Uchida H., Udell G.F., and Yamori N. (2011) [45] have had different findings, and these scholars believe that the information scoring system, information technology and funds of the big banks are more advantageous than those of the small- and medium-sized banks, so the large banks are more suitable for issuing loans to small- and medium-sized enterprises. The domestic scholars Yao Yaojun and Dong Gangfeng (2015) [46] believe that the adjustment of the banking structure and the promotion of the development of small- and medium-sized banks will be able to provide more channels for the financing of small- and medium-sized enterprises, which also has an anti-poverty economic effect. However, De La Torre A., Peria M.S.M., and Schmukler S.L. (2010) [47] think that the big banks are willing to offer loans to smalland medium-sized enterprises under the drive of profit. What's more, the big banks are able to provide various products and services for small enterprises in China, and they have a perfect risk management system. Therefore, in the process of financing for small- and medium-sized enterprises, the big banks have more comparative advantages than small- and medium-sized banks. 
To sum up, the research on alleviating the financing constraints of small- and medium-sized enterprises has made a lot of achievements, which is the basis of this study, but there are still some deficiencies, which are reflected in the following aspects. First of all, most of the existing research is based on the internal factors and financial deepening of small- and medium-sized enterprises, great importance has been attached to the development of the enterprise itself, the marketization of financing costs and the diversification of financing channels to alleviate the financing constraints of small- and medium-sized enterprises, while it has neglected that the fundamental cause of the financing difficulties of small- and medium-sized enterprises is information asymmetry, which is closely related to the financial structure. Second, as for the financial structural factors, in spite of the fact that it has been elaborated in the literature at home and abroad, they mostly stay at the qualitative description and theoretical analysis, while few have been involved in the introduction of mathematical models and the further analysis by the empirical test. In particular, few empirical studies on Chinese enterprises are involved. Third, the financial structure factors include the banking structure, and the scale ratio of banks to other financial institutions, while the latter has hardly been involved in the existing research. On the basis of previous studies, this paper focuses on the impact of financial structure factors on the financing constraints of small and medium enterprises in China, and establishes an econometric model for the empirical test, so as to find out the external conditions that affect the financing of small- and medium-sized enterprises, and to explore the optimal arrangement for the financial system, as well as to provide some relatively effective suggestions for the current financial reform.

\subsection{Theoretical Hypothesis}

Yifu Lin (2009) [48] put forward the theory of "optimal financial structure", which has laid emphasis on the importance of the scale and structure of the banking industry to economic growth. The central idea is that the regional small- and medium-sized banks in the developing countries should be the main components of the financial system, in order to realize the optimal allocation of financial resources, to adapt the financial structure to the industrial structure and thus to promote the economic development. Therefore, the following hypotheses are put forward in this paper.

Hypothesis 1. The factor endowment structure of an economy determines its optimal industrial structure.

The factor endowment structure varies in the developing countries and developed countries, which determines that some systematic differences are shown in their industrial structures of real economy. Different industries have different needs for financing, risk characteristics, and information transparency, so there are significant differences in demand for financial resources among different economies. As a developing country, China has abundant labor resources, and its labor-intensive industries have comparative advantages, while these enterprises are mostly small- and medium-sized enterprises, which, as a result, have become the main types of enterprises in the optimal industrial structure at the present stage of China.

Hypothesis 2. The optimal financial structure must be able to adapt to the industrial structure and meet the needs of the small-and medium-sized enterprises for funds.

Small- and medium-sized enterprises have a small financing scale, and relatively opaque information, and there is a lack of complete financial statements, mortgaged assets and other "hard information" that is easy to transfer, so that the information asymmetry has become the fundamental reason for impeding its financing and completing financial transactions. Relative to large enterprises, SME financing is more dependent on the "soft information", such as the business ability of the entrepreneur, the trustee-beneficiary relationship between the management level and the owner, which is mostly the specific information about specific objects. And it has the characteristics of fuzziness and personification, so it is difficult to quantify such information for statistics in the form 
of standard data. Then the fund suppliers have to reduce the degree of information asymmetry by searching for the information related to the enterprise and the entrepreneur, and to strengthen the selection, supervision, and control of the enterprise managers through a certain contract arrangement and governance mechanism, so as to reduce the investment risk. In the banking structure that leads the financial industry in China, the proportion of large state-owned banks and regional small- and medium-sized banks must be rationally arranged so that they can separately allocate funds on the basis of their own advantages, so as to fully meet the financing needs of all kinds of enterprises.

Hypothesis 3. The optimal financial structure should be based on the division of labor based on specialization in the banking industry, that is, large banks provide loans to large enterprises mainly, and small banks mainly provide loans to small businesses, which is mainly based on two factors.

On the one hand, from the perspective of capital supply capacity, the large banks with a large scale of assets have the ability to provide financial services, such as credit and financial leasing, to large enterprises with great capital demand, while small- and medium-sized banks with a small scale of assets are difficult to provide large amounts of loans. On the other hand, in terms of the ability to overcome information asymmetry, the big banks are more suitable for supervising large-scale enterprises, while small- and medium-sized banks have comparative advantages in monitoring small enterprises, the reason for which is that the large enterprises generally have the complete and audited financial statements, a plenty of mortgaged assets and relatively complete credit records, and they have more "hard information" in loan financing. As a result, the financial institutions with systematic credit evaluation mechanism have advantages in dealing with "hard information". However, the smalland medium-sized enterprises lack the "hard information" like this, and they have a relatively short term of credit records. Whether the banks provide a loan to them often rely on the "soft information" which is difficult to quantify, such as entrepreneurs' management ability, personal quality, and the principal-agent relationship. Therefore, only the financial institutions that are prone to obtaining and processing the "soft information" can overcome the problem of information asymmetry in the financing of small- and medium-sized enterprises.

In large banks, the complex organizational structure has lengthened the chain of information transmission within the bank. It is difficult to transfer the "soft information" of the enterprise, and it is weak in the incentives for the bank clerks to collect the "soft information" of the customers, while the "hard information", such as the enterprise's financial statements and the mortgaged assets, is easily transmitted, so that "hard information" has become an evaluation criterion for large banks to make credit decisions. Therefore, large banks are suitable to provide loans to large enterprises with relatively transparent information but may encounter information block when lending to the small- and medium-sized enterprises. In the small- and medium-sized banks, it has a short chain of information transmission within the bank, and the decision-makers are able to make an effective use of the "soft information" of the enterprise to make the decisions, and there are relatively strong incentives for collecting "soft information". At the same time, the small- and medium-sized banks are mostly regional banks, which can facilitate the establishment of long-term credit relations with adjacent smalland medium-sized enterprises, and the relationship-based credit is also beneficial to make up for the failure of the credit market. Thus, small- and medium-sized banks have comparative advantages in the financing of small- and medium-sized enterprises. As a result, the support for the development of small- and medium-sized banks, the expansion of the share of the small- and medium-sized banks in the banking industry and the optimization of the financial structure will be conductive to the effective allocation of funds and the development of small- and medium-sized enterprises, thus driving the economic growth.

In the light of the theoretical logic of the new structural economics, it can be concluded that improving the status of small- and medium-sized banks is the key to optimizing the financial structure and solving the financing problems of small- and medium-sized enterprises. Then, how should the 
financing constraints for small- and medium-sized enterprises be? Is the development of small- and medium-sized banks able to significantly alleviate their financing constraints?

\section{Model, Data and Variables}

\subsection{Model Setting}

As a classic, the theory of Modigliani and Miller (1958) [49] has provided a standard model and logical starting point for the research on corporate finance. In accordance with the MM (Modigliani Miller) theorem, the internal and external financing of the enterprise can be completely replaced within the perfect and frictionless financial market, and the investment behavior is not affected by the financial situation of the company, but is only related to the investment demand of the enterprise. However, the real financial market is not perfect, the information asymmetry and the agency problem have made the external financing cost usually higher than the internal financing cost. The investment decision of enterprises is endogenous from the financing capacity of the enterprise, and such imperfections of the financial markets are embodied as "financing constraints" at the enterprise level.

The investment-cash flow sensitivity model proposed by Fazzari, Hubbard, and Petersen (1988) [50] has greatly quantified the financing constraints of the enterprise. Corporate cash flow represents investment opportunities and future earnings, which is the internal financing of an enterprise. Investment expenditure represents the project investment of the enterprise. The sensitivity of investment expenditure to cash flow reflects the financing constraints of the enterprise. The more sensitive the investment is to the cash flow, the more difficult the external financing will be, so that the enterprise will be confronted with financing constraints. After that, Laeven (2003) [51] and Bond (1994) [52] perfected the investment-cash flow sensitivity model on this basis, and the basic equation can be expressed as:

$$
\left(\frac{\mathrm{I}}{\mathrm{K}}\right)_{i, t}=B_{0}+B_{1}\left(\frac{\mathrm{Y}}{\mathrm{K}}\right)_{i, t-1}+B_{2}\left(\frac{\mathrm{CF}}{\mathrm{K}}\right)_{i, t-1}+\varepsilon i, t .
$$

The variables in the model are the internal conditions of the enterprise (financial information), in which $\mathrm{I}$ is the investment expenditure of the enterprise, $\mathrm{Y}$ is the main business income, and CF is the cash flow. These variables are measured by $K$, which represents the total value of assets. The coefficient $B_{2}$ indicates the sensitivity of investment to cash flow. If an enterprise's investment in the period $t$ depends on the internal cash flow of the $t-1$ period, that is, $B_{2}>0$, the enterprise will be faced with financing constraints.

This model is also applicable to the empirical research on financing constraints of Chinese enterprises. Poncet, Steingress, and Vandenbussche (2010) [23] adopted the investment-cash flow sensitivity model to test the financing constraints of Chinese enterprises from 1998 to 2005 . Kenneth S. Chan, Vinh Q.T. Dang, and Isabel K.M. Yan (2012) [53] expanded this model to study the impact of the political relations on the financing constraints for Chinese enterprises. On the basis of this model, Chinese scholars, such as Shen Hongbo (2010) [54], have studied the relationship between the financial development and corporate financing constraints. These rich research results provide an empirical basis for the application of this model in this paper.

In order to measure the role of the development of small- and medium-sized banks in alleviating the financing constraints of small- and medium-sized enterprises, this paper assumes that the difference in the cost of information production caused by information asymmetry is the cause of the specialized division of labor between large banks and small- and medium-sized banks, not taking into account the agency cost. In spite of the fact that the big bank has a more complex internal hierarchical structure and high agency costs, its equity is more open than that of the small- and medium-sized banks. The function of control transfer in the capital market and the incentive mechanism of options will be able to alleviate the agency problem. Therefore, considering both internal and external agency costs, this paper assumes that the agency cost variance of banks has little effect on the financing of small- 
and medium-sized enterprises. In accordance with the fundamental model (1), the following extended model is established:

$$
\begin{aligned}
& \left(\frac{\mathrm{I}}{\mathrm{K}}\right)_{i, t}=B_{0}+B_{1}\left(\frac{\mathrm{Y}}{\mathrm{K}}\right)_{i, t-1}+B_{2}\left(\frac{\mathrm{CF}}{\mathrm{K}}\right)_{i, t-1}+B_{3}\left(\frac{\mathrm{CF}}{\mathrm{K}}\right)_{i, t-1} \times \mathrm{SMB}_{i, t}+ \\
& B_{4}\left(\frac{\mathrm{CF}}{\mathrm{K}}\right)_{i, t-1} \times \mathrm{BS}_{i, t}+B_{5}\left(\frac{\mathrm{CF}}{\mathrm{K}}\right)_{i, t-1} \times\left(\frac{\mathrm{B}}{\mathrm{GDP}}\right)_{i, t}+B_{6}\left(\frac{\mathrm{CF}}{\mathrm{K}}\right)_{i, t-1} \times\left(\frac{\mathrm{S}}{\mathrm{GDP}}\right)_{i, t}+a_{i}+ \\
& e_{t}+\varepsilon i, t .
\end{aligned}
$$

On the basis of the fundamental model (1), this extended model has added the external conditions that affect the financing of small- and medium-sized enterprises, and taken the interaction items between them and the cash flow $\mathrm{CF} / \mathrm{K}$ to measure the influence of these factors on the financing constraints of enterprises. First of all, SMB is the position of small- and medium-sized banks in the banking sector of the province where the enterprise $i$ is located, which is the main concern in the preceding part. Second, the proportion of the banking industry to the capital market BS, in the financial system, is also likely to affect the investment of the enterprise. It is also one of the channels for the financing of small- and medium-sized enterprises to be listed through the stock market. Third, the variable that reflects the development level of the financial industry is the development level of the regional banking industry $\mathrm{B} / \mathrm{GDP}$, and the development level of the regional capital market S/GDP will also affect the difficulty of the business financing. Finally, in the coefficients of each explanatory variable, $\beta_{3}$ is the key parameter to test whether the development of small- and medium-sized banks can alleviate the financing constraints of small- and medium-sized enterprises. In the case that $\beta_{3}<0$, it indicates that corporate investment is less dependent on internal cash flow, the promotion of the status of small- and medium-sized banks can alleviate the financing constraints on the small- and medium-sized enterprises. $\beta_{4}, \beta_{5}$, and $\beta_{6}$, respectively reflect the impact of the structural changes of the whole financial industry, the level of banking development and the level of capital market development on the financing constraints of the small- and medium-sized enterprises.

The extended Equation (2) also incorporates the time effects and individual effects, thus establishing a static panel model for a two-way fixed effect.

\subsection{Data and Variables}

The sample used in this paper is 161 companies in China's SME Board from 2009 to 2013, which are distributed in 32 provinces and municipalities directly under the central government in China. The corporate financial data on the internal financing conditions are derived from the financial statement database of the listed companies in China by the GTA CSMAR database. And the regional financial data on the external financing conditions is sorted out based on the "Almanac of China's Finance and Banking 2014" and "Report on China's Regional Financial Operation" from 2009 to 2013 issued by the People's Bank of China. After collecting the financial data of the SME Board, this paper has also screened out a part of samples, including small- and medium-sized banks, companies with the asset-liability ratio larger than 1, ST(Special Treatment) companies and the companies with negative cash flow CF. These samples have certain problems, such as insolvency, difficulties in operation and endogenous financing, so that they cannot be taken as research objects. Finally, we get panel data from 161 companies.

The explained variable in this paper is the investment expenditure I/K measured by total assets. The explanatory variables include internal financing conditions and external financing conditions of the enterprise. $\mathrm{Y} / \mathrm{K}$, and $\mathrm{CF} / \mathrm{K}$ represent the internal financing conditions of the enterprise, $\mathrm{SMB}$, $\mathrm{BS}, \mathrm{B} / \mathrm{GDP}, \mathrm{S} / \mathrm{GDP}$ represent the external financing conditions, in which SMB and BS represent the financial structure, and B/GDP and S/GDP represent the level or degree of the development of the financial industry. The specific definitions and sources of the variables are shown in Table 1. 
Table 1. Definitions of the variables.

\begin{tabular}{|c|c|c|c|}
\hline Variable Symbol & Variable Name & Variable Definition & Data Sources \\
\hline I & Investment expenditure & $\begin{array}{l}\text { Expenditure on the construction } \\
\text { of fixed assets, intangible assets } \\
\text { and other long-term assets }\end{array}$ & $\begin{array}{l}\text { CSMAR Database-Cash Flow } \\
\text { Statements of Enterprises }\end{array}$ \\
\hline $\mathrm{K}$ & Total assets & $\begin{array}{l}\text { Total assets at the beginning of the } \\
\text { period }\end{array}$ & $\begin{array}{l}\text { CSMAR Database-Balance } \\
\text { Sheets OF Enterprises }\end{array}$ \\
\hline Y & Total output & Main business income & $\begin{array}{l}\text { CSMAR Database-Income } \\
\text { Statements of Enterprises }\end{array}$ \\
\hline $\mathrm{CF}$ & Cash flow & $\begin{array}{l}\text { Net cash flow generated by } \\
\text { business activities }\end{array}$ & $\begin{array}{l}\text { CAMAR Database-Cash } \\
\text { Flow Statements of Enterprises }\end{array}$ \\
\hline SMB & $\begin{array}{l}\text { Status of small- and } \\
\text { medium-sized banks in the } \\
\text { banking industry }\end{array}$ & $\begin{array}{l}\text { Total assets of small- and } \\
\text { medium-sized banks in the } \\
\text { region/total assets of the regional } \\
\text { banking industry }{ }^{1}\end{array}$ & $\begin{array}{l}\text { Report on China's Regional } \\
\text { Financial Operation } \\
\text { (2009-2013) }\end{array}$ \\
\hline BS & $\begin{array}{l}\text { Proportion of the banking } \\
\text { industry to the capital market }\end{array}$ & $\begin{array}{c}\text { Loan balance of regional financial } \\
\text { institutions B/total market value } \\
\text { of regional shares } \mathrm{S}\end{array}$ & $\begin{array}{l}\text { Almanac of China's Finance } \\
\text { and Banking } 2014\end{array}$ \\
\hline B/GDP & $\begin{array}{l}\text { Development level of the } \\
\text { banking industry }\end{array}$ & $\begin{array}{l}\text { Loan balance of regional financial } \\
\text { institutions B/regional GDP }\end{array}$ & $\begin{array}{l}\text { Almanac of China's Finance } \\
\text { and Banking } 2014\end{array}$ \\
\hline S/GDP & $\begin{array}{l}\text { Development level of the } \\
\text { capital market }\end{array}$ & $\begin{array}{l}\text { Total market value of regional } \\
\text { shares S/regional GDP }\end{array}$ & $\begin{array}{l}\text { Almanac of China's Finance } \\
\text { and Banking } 2014\end{array}$ \\
\hline
\end{tabular}

In view of the above sample data, we obtained the descriptive statistical results of the main variables with the aid of Stata (see Table 2).

Table 2. Descriptive statistics of major variables.

\begin{tabular}{cccccc}
\hline Variable & $\begin{array}{c}\text { Mean } \\
\text { Value }\end{array}$ & $\begin{array}{c}\text { Standard } \\
\text { Deviation }\end{array}$ & $\begin{array}{c}\text { Minimum } \\
\text { Value }\end{array}$ & $\begin{array}{c}\text { Maximum } \\
\text { Value }\end{array}$ & $\begin{array}{c}\text { Number of } \\
\text { Observations }\end{array}$ \\
\hline I/K & 0.106 & 0.084 & 0.000 & 0.612 & 805 \\
Y/K & 0.857 & 0.485 & 0.061 & 3.160 & 805 \\
CF/K & 0.115 & 0.089 & 0.000 & 0.721 & 805 \\
SMB & 0.544 & 0.103 & 0.033 & 0.714 & 160 \\
BS & 3.899 & 2.325 & 0.243 & 15.610 & 160 \\
B/GDP & 1.174 & 0.425 & 0.563 & 2.738 & 160 \\
S/GDP & 0.640 & 1.313 & 0.095 & 10.535 & 160 \\
\hline
\end{tabular}

After descriptive statistics of the selected variables, considering the possibility of multiple collinearity, the correlation coefficient matrix of each variable is obtained.

The results in Table 3 show that the correlation coefficient among the variables is very small, and the model does not have the problem of multiple collinearity. It should be noted that the correlation coefficient between $\mathrm{BS}$ and $\mathrm{B} / \mathrm{GDP}$ and $\mathrm{S} / \mathrm{GDP}$ is large. Because $\mathrm{BS}$ is the ratio of $\mathrm{B}$ to $\mathrm{S}$, it has a great correlation with $\mathrm{B} / \mathrm{GDP}$ and $\mathrm{S} / \mathrm{GDP}$. It does not affect the validity of the main explanatory variables such as $\mathrm{CFP} / \mathrm{K}, \mathrm{SMB}$, and the model. 
Table 3. The person of correlation coefficient matrix.

\begin{tabular}{cccccccc}
\hline Correlation & I/K & Y/K & CF/K & SMB & BS & B/GDP & S/GDP \\
\hline I/K & 1 & & & & & & \\
Y/K & 0.0163 & 1 & & & & & \\
CF/K & 0.1011 & 0.2903 & 1 & & & & \\
SMB & -0.0060 & -0.0657 & -0.2100 & 1 & & & \\
BS & -0.0001 & -0.0400 & -0.1420 & 0.1815 & 1 & & \\
B/GDP & -0.0377 & 0.0125 & 0.0049 & 0.0855 & -0.4432 & 1 & \\
S/GDP & -0.0598 & -0.0214 & 0.0728 & -0.1681 & -0.5862 & 0.2852 & 1 \\
\hline
\end{tabular}

\section{Result Analysis}

\subsection{Recognition Result Analysis}

The model (2) is a static panel model based on the data of 161 small- and medium-sized enterprises for 5 years. The value of $p$ obtained by the Hausman test is 0.00 , so the original hypothesis cannot be accepted and the fixed effect model is used to estimate. At the same time, we take control of the individual effect $a_{i}$ and the time effect $e_{t}$, and carry out the estimation of the two-way fixed effects. In the estimation process, the interaction terms of the four external conditions, namely, SMB, BS, B/GDP, S/GDP, and cash flow are added into the model to test.

The regression of Table 4 shows that the coefficient of $C F / K_{2}$ is greater than 0 , and it is significant at the significant level of $5 \%$, which indicates that the investment expenditure of small- and medium-sized enterprises is sensitive to cash flow. In the case of inadequacy of the internal cash flow, the investment expenditure is significantly reduced in the enterprise, indicating that the enterprise is difficult to obtain financing from the outside to support the investment activities, that is, there are external financing constraints. The coefficient of the interaction item of the status of small- and medium-sized banks and the cash flow $\mathrm{B}_{3}$ is less than 0 , and it is significant at the significant level of $5 \%$, which indicates that the improvement of the status of small- and medium-sized banks is able to reduce the investment-cash flow sensitivity of enterprises and to alleviate the financing constraints of small- and medium-sized enterprises. The larger the size of the small- and medium-sized banks in the banking industry is, the greater the possibility and the limit of the small- and medium-sized enterprises to obtain loans will be, so that the enterprises will be less dependent on the internal cash flow in case of investment, which is in line with the theoretical hypothesis of this paper. In addition, after the joint test of the coefficients of each explanatory variable, the F statistic is significant at the significance level of $1 \%$, which shows that the above regression is effective.

From the results of regression $3,4,6,7$, and 8 , we can see that the coefficient of the interaction item between the development level of the banking industry B/GDP and the development level of the capital market S/GDP and the cash flow $\mathrm{CF} / \mathrm{K}$ are not significantly different from 0 . Therefore, the improvement of the development level of the financial market isn't an effective way to solve the financing difficulty of the small- and medium-sized enterprises. In the event that the scale of the capital market is enlarged, the degree of financial freedom will be enhanced, but it is still difficult for the smalland medium-sized enterprises to carry out equity financing. Even the Growth Enterprise Market (GEM) and the SME Board have a high threshold in terms of asset size, profitability, and business period. Therefore, most of the beneficiaries from the enhancement of the financial markets are likely to be the large enterprises that are listed on the Main Board. Despite the fact that the increase in the loan balance of the banking industry and in the total market value of the capital market have promoted the development of the financial market on the whole, the Chinese enterprises are also able to obtain more financing, but the broadening of the financial market does not mean that the market is deepened. In fact, the channels for small- and medium-sized enterprises to obtain financing have not yet been opened, and the expansion of the financial market in scale is difficult to ease their financing constraints. The credit block caused by information asymmetry is the crux of the financing difficulties of small- and 
medium-sized enterprises, which is consistent with the reality that the banking industry dominates China's financial industry.

Table 4. Results of model estimation.

\begin{tabular}{|c|c|c|c|c|c|c|c|c|}
\hline & Reg1 & $\operatorname{Reg} 2$ & Reg3 & $\operatorname{Reg} 4$ & Reg5 & Reg6 & Reg7 & Reg8 \\
\hline $\mathrm{Y} / \mathrm{K}$ & $\begin{array}{c}0.019 \\
(0.012)\end{array}$ & $\begin{array}{c}0.018 \\
(0.012)\end{array}$ & $\begin{array}{c}0.018 \\
(0.012)\end{array}$ & $\begin{array}{c}0.018 \\
(0.012)\end{array}$ & $\begin{array}{c}0.018 \\
(0.012)\end{array}$ & $\begin{array}{c}0.018 \\
(0.012)\end{array}$ & $\begin{array}{c}0.018 \\
(0.012)\end{array}$ & $\begin{array}{c}0.018 \\
(0.012)\end{array}$ \\
\hline $\mathrm{CF} / \mathrm{K}$ & $\begin{array}{l}0.629 * * \\
(0.266)\end{array}$ & $\begin{array}{l}0.632 \text { ** } \\
(0.266)\end{array}$ & $\begin{array}{l}0.697^{* *} \\
(0.273)\end{array}$ & $\begin{array}{l}0.645 * * \\
(0.267)\end{array}$ & $\begin{array}{l}0.697 * * \\
(0.274)\end{array}$ & $\begin{array}{l}0.644^{* *} \\
(0.268)\end{array}$ & $\begin{array}{c}0.702 \\
(0.274)\end{array}$ & $\begin{array}{l}0.701^{* *} \\
(0.274)\end{array}$ \\
\hline $\begin{array}{l}\text { SMB Interacting } \\
\text { with } \mathrm{CF} / \mathrm{K}\end{array}$ & $\begin{array}{l}-1.188^{* *} \\
(0.482)\end{array}$ & $\begin{array}{l}-1.244^{* *} \\
(0.500)\end{array}$ & $\begin{array}{l}-1.106^{* *} \\
(0.488)\end{array}$ & $\begin{array}{l}-1.193 * * \\
(0.483)\end{array}$ & $\begin{array}{l}-1.114^{* *} \\
(0.526)\end{array}$ & $\begin{array}{l}-1.214^{* *} \\
(0.505)\end{array}$ & $\begin{array}{l}-1.090 \\
(0.495)\end{array}$ & $\begin{array}{l}-1.109 * * \\
(0.517)\end{array}$ \\
\hline $\begin{array}{l}\text { BS Interacting with } \\
\text { CF } / \mathrm{K}\end{array}$ & & $\begin{array}{l}-0.009 \\
(0.021)\end{array}$ & & & $\begin{array}{l}-0.001 \\
(0.022)\end{array}$ & $\begin{array}{c}-0003 \\
(-0.024)\end{array}$ & & $\begin{array}{l}-0.003 \\
(0.024)\end{array}$ \\
\hline $\begin{array}{l}\text { B/GDP Interacting } \\
\text { with } \mathrm{CF} / \mathrm{K}\end{array}$ & & & $\begin{array}{c}0.086 \\
(0.077)\end{array}$ & & $\begin{array}{c}0.085 \\
(0.082)\end{array}$ & & $\begin{array}{c}0.100 \\
(0.106)\end{array}$ & $\begin{array}{c}0.100 \\
(0.106)\end{array}$ \\
\hline $\begin{array}{l}\text { S/GDP Interacting } \\
\text { with } \mathrm{CF} / \mathrm{K}\end{array}$ & & & & $\begin{array}{c}0.017 \\
(0.028)\end{array}$ & & $\begin{array}{c}0.015 \\
(0.032)\end{array}$ & $\begin{array}{l}-0.008 \\
(0.039)\end{array}$ & $\begin{array}{l}-0.010 \\
(0.042)\end{array}$ \\
\hline Year2011 & $\begin{array}{l}-0.003 \\
(0.007)\end{array}$ & $\begin{array}{l}-0.002 \\
(0.008)\end{array}$ & $\begin{array}{l}-0.001 \\
(0.007)\end{array}$ & $\begin{array}{l}-0.002 \\
(0.007)\end{array}$ & $\begin{array}{l}-0.001 \\
(0.008)\end{array}$ & $\begin{array}{l}-0.001 \\
(0.008)\end{array}$ & $\begin{array}{l}-0.002 \\
(0.007)\end{array}$ & $\begin{array}{l}-0.001 \\
(0.008)\end{array}$ \\
\hline Year2012 & $\begin{array}{c}-0.034^{* * *} \\
(0.007)\end{array}$ & $\begin{array}{c}-0.033 * * * \\
(0.008)\end{array}$ & $\begin{array}{c}-0.033^{* * *} \\
(0.008)\end{array}$ & $\begin{array}{c}-0.329^{* * *} \\
(0.008)\end{array}$ & $\begin{array}{c}-0.033^{* * *} \\
(0.008)\end{array}$ & $\begin{array}{c}-0.033^{* * *} \\
(0.008)\end{array}$ & $\begin{array}{c}-0.033^{* * * *} \\
(0.007)\end{array}$ & $\begin{array}{c}-0.033^{* * *} \\
(0.008)\end{array}$ \\
\hline Year2013 & $\begin{array}{c}-0.047^{* * *} \\
(0.008)\end{array}$ & $\begin{array}{c}-0.046^{* * *} \\
(0.008)\end{array}$ & $\begin{array}{c}-0.046^{* * *} \\
(0.008)\end{array}$ & $\begin{array}{c}-0.457^{* * *} \\
(0.008)\end{array}$ & $\begin{array}{c}-0.046^{* * *} \\
(0.008)\end{array}$ & $\begin{array}{c}-0.045^{* * *} \\
(0.008)\end{array}$ & $\begin{array}{c}-0.046^{* * *} \\
(0.008)\end{array}$ & $\begin{array}{c}-0.046^{* * *} \\
(0.008)\end{array}$ \\
\hline $\begin{array}{l}\text { Joint test of F } \\
\text { statistics }\end{array}$ & $12.55^{* * *}$ & $10.76^{* * *}$ & $10.94^{* * *}$ & $10.80 * * *$ & $9.55^{* * *}$ & $9.43^{* * *}$ & $9.56^{* * *}$ & $8.48^{* * *}$ \\
\hline Observation & 644 & 644 & 644 & 644 & 644 & 644 & 644 & 644 \\
\hline
\end{tabular}

Note $1:{ }^{*}, * * * * *$ indicate that it is significant at the significance levels of $10 \%, 5 \%$, and $1 \%$ respectively. Note 2 : The values in the table are the coefficients of the variables and those in the brackets are their standard errors.

Therefore, starting from the perspective of financial structure, the financing constraints of smalland medium-sized enterprises can be effectively alleviated, but the regression of Table 3 shows that the coefficient of the interaction item between the proportion of financial institutions BS and the cash flow is not significantly different from 0 . And thus, the increase in the proportion of the scale of banking loans to the total market value of the capital market is still unable to significantly reduce the investment-cash flow sensitivity. Then the financial structural factors that can alleviate the financing constraints of small- and medium-sized enterprises should be based on the banking structure, paying attention to the status of the small- and medium-sized banks in the banking industry, rather than the scale ratio of the banking industry to other financial institutions.

\subsection{Robustness Test}

Considering that both the investment and financing constraints of enterprises have some persistent characteristics, the model is extended to a dynamic panel model by adding the lag term of the explained variable to the explanatory variable. At the same time, we need to consider the endogenous issues. On the one hand, the introduction of the lag term can reduce the set error of the model, but also increases the endogeneity. On the other hand, the enterprise's output $Y$ may lead to endogenous. The latter comes from the fact that the amount of output means the ability and possibility of long-term investment. So even if there is no financing constraint, the investment ability and possibility will have an impact on the investment decision of the firm. 
Therefore, in order to make the empirical analysis more robust, on the basis of the fixed effect model based on static panel:

$$
\begin{aligned}
\left(\frac{\mathrm{I}}{\mathrm{K}}\right)_{i, t}=B_{0}+ & B_{1}\left(\frac{\mathrm{I}}{\mathrm{K}}\right)_{i, t-1}+B_{2}\left(\frac{\mathrm{Y}}{\mathrm{K}}\right)_{i, t-1}+B_{3}\left(\frac{\mathrm{CF}}{\mathrm{K}}\right)_{i, t-1} B_{4}\left(\frac{\mathrm{CF}}{\mathrm{K}}\right)_{i, t-1} \times \mathrm{SMB}_{i, t} \\
& +B_{5}\left(\frac{\mathrm{CF}}{\mathrm{K}}\right)_{i, t-1} \times \mathrm{BS}_{i, t}+B_{6}\left(\frac{\mathrm{CF}}{\mathrm{K}}\right)_{i, t-1} \times\left(\frac{\mathrm{B}}{\mathrm{GDP}}\right)_{i, t} \\
& +B_{7}\left(\frac{\mathrm{CF}}{\mathrm{K}}\right)_{i, t-1} \times\left(\frac{\mathrm{S}}{\mathrm{GDP}}\right)_{i, t}+a_{i}+e_{t}+\varepsilon i, t .
\end{aligned}
$$

Because the panel data in this paper has the characteristic of " $T$ is smaller and $n$ is bigger", the GMM method is considered for the endogenetic problem of short dynamic panel. In terms of tool variables, we need to find out the tool variables of two endogenous variables such as $\left(\frac{\mathrm{I}}{\mathrm{K}}\right)_{i, t-1}$ and $\left(\frac{Y}{K}\right)_{i, t-1}$. In this paper, the second order and higher order delay terms of two endogenous variables are selected as tool variables. According to the method proposed by Arellano and Bond (1991), the GMM estimation of the differential equation is carried out, and it is assumed that the subsequent perturbation terms do not have autocorrelation. In addition, considering that there may be a correlation between the tool variables of $\left(\frac{\mathrm{I}}{\mathrm{K}}\right)_{i, t-1}$ and the individual effect $a_{i}$, there may be a deviation between the horizontal GMM and the systematic GMM estimation, so the differential GMM estimation is carried out. The estimated results are as follows.

As can be seen from the results of Table 5: first, the results of the Arellano and Bond test show that the difference of the perturbation term has first order autocorrelation, but there is no second order autocorrelation. As a consistent estimate, the differential GMM is based on the assumption that the disturbance term does not have autocorrelation, which should be tested by AR. From the results of Table 5, we cannot reject the original assumption that "there is no autocorrelation". So the difference GMM estimate in this paper is valid. Second, the $p$ value of Sargen test is large, so we cannot reject the original hypothesis that "Tool variable is effective". The hysteretic terms of the explained variables, $\mathrm{Y} / \mathrm{K}$ and $\mathrm{CF} / \mathrm{K}$ are used as tool variables which satisfies the exogenetic requirements. Third, comparing Tables 4 and 5, considering the endogenous problem and using dynamic panel estimation, the coefficient of the lagged term is significantly greater than 0 , and is significant at the significant level of $1 \%$. This indicates that the investment in the previous period is the barometer of the investment in the next period, and the investment decision of the enterprise is not transient but continuous and consistent. Fourth, the coefficients of the core variable $\mathrm{CF} / \mathrm{K}$ and the interaction between $\mathrm{SMB}$ and $\mathrm{CF} / \mathrm{K}$ are still significant, and they are significantly increased in the four columns of reg3, reg5, reg7, and reg8. The four regression was significantly elevated from a significant level of $5 \%$ to a significant level at a significant level of $1 \%$. The results show that the investment of Small and Micro enterprises is really sensitive to cash flow and they face constraints in the process of financing, and the expansion of the scale of small- and medium-sized banks in the banking industry can significantly alleviate the financing constraints of Small and Micro enterprises; Fifth, in the three columns of Reg4, reg6, and reg7, the coefficient of the interaction between S/GDP and CF/K is less than 0 and is significant under the significant level of $10 \%$. This indicates that the development of the stock market can also solve the financing problem of small- and medium-sized enterprises to a certain extent. In general, the results of GMM (Generalized Method of Moments) estimate confirm the conclusion that the development of small- and medium-sized banks can effectively alleviate the financing constraints of Small and Micro enterprises. 
Table 5. Difference GMM estimation results.

\begin{tabular}{|c|c|c|c|c|c|c|c|c|}
\hline & Reg1 & Reg2 & Reg3 & Reg4 & Reg5 & Reg6 & Reg7 & Reg8 \\
\hline Lag_I & $\begin{array}{l}0.640 * * * \\
(0.089)\end{array}$ & $\begin{array}{l}0.636^{* * *} \\
(0.091)\end{array}$ & $\begin{array}{l}0.635^{* * * *} \\
(0.086)\end{array}$ & $\begin{array}{l}0.629 * * * \\
(0.084)\end{array}$ & $\begin{array}{l}0.633^{* * *} \\
(0.088)\end{array}$ & $\begin{array}{l}0.627^{* * *} \\
(0.090)\end{array}$ & $\begin{array}{l}0.635^{* * *} \\
(0.088)\end{array}$ & $\begin{array}{l}0.633^{* * *} \\
(0.094)\end{array}$ \\
\hline $\mathrm{Y} / \mathrm{K}$ & $\begin{array}{c}0.003 \\
(0.009)\end{array}$ & $\begin{array}{c}0.003 \\
(0.009)\end{array}$ & $\begin{array}{c}0.003 \\
(0.009)\end{array}$ & $\begin{array}{c}0.004 \\
(0.009)\end{array}$ & $\begin{array}{c}0.003 \\
(0.009)\end{array}$ & $\begin{array}{c}0.005 \\
(0.012)\end{array}$ & $\begin{array}{c}0.004 \\
(0.009)\end{array}$ & $\begin{array}{c}0.005 \\
(0.009)\end{array}$ \\
\hline $\mathrm{CF} / \mathrm{K}$ & $\begin{array}{l}0.424^{* *} \\
(0.261)\end{array}$ & $\begin{array}{l}0.418^{* *} \\
(0.262)\end{array}$ & $\begin{array}{c}0.435^{* * *} \\
(0.266)\end{array}$ & $\begin{array}{l}0.462 * * \\
(0.289)\end{array}$ & $\begin{array}{l}0.429^{* * *} \\
(0.273)\end{array}$ & $\begin{array}{l}0.451^{* *} \\
(0.322)\end{array}$ & $\begin{array}{c}0.474^{* * *} \\
(0.303)\end{array}$ & $\begin{array}{l}0.468 * * * \\
(0.339)\end{array}$ \\
\hline $\begin{array}{l}\text { SMB Interacting } \\
\text { with CF/K }\end{array}$ & $\begin{array}{l}-1.718^{* *} \\
(0.448)\end{array}$ & $\begin{array}{l}-1.713^{* *} \\
(0.447)\end{array}$ & $\begin{array}{l}-1.721^{* * *} \\
(0.445)\end{array}$ & $\begin{array}{l}-1.730 * * \\
(0.490)\end{array}$ & $\begin{array}{l}-1.707^{* * * *} \\
(0.439)\end{array}$ & $\begin{array}{l}-1.732 * * \\
(0.516)\end{array}$ & $\begin{array}{l}-1.822 * * * \\
(0.531)\end{array}$ & $\begin{array}{l}-1.863^{* * *} \\
(0.560)\end{array}$ \\
\hline $\begin{array}{l}\text { BS Interacting with } \\
\text { CF } / \mathrm{K}\end{array}$ & & $\begin{array}{l}-0.009 * * \\
(0.021)\end{array}$ & & & $\begin{array}{l}-0.003 \\
(0.022)\end{array}$ & $\begin{array}{l}-0.030 \\
(-0.045)\end{array}$ & & $\begin{array}{c}-0.030^{* * *} \\
(0.045)\end{array}$ \\
\hline $\begin{array}{l}\text { B/GDP Interacting } \\
\text { with } \mathrm{CF} / \mathrm{K}\end{array}$ & & & $\begin{array}{c}0.068 \\
(0.076)\end{array}$ & & $\begin{array}{c}0.072 \\
(0.107)\end{array}$ & & $\begin{array}{c}0.148 \\
(0.129)\end{array}$ & $\begin{array}{c}0.132 \\
(0.122)\end{array}$ \\
\hline $\begin{array}{l}\text { S/GDP Interacting } \\
\text { with } \mathrm{CF} / \mathrm{K}\end{array}$ & & & & $\begin{array}{l}-0.057^{*} \\
(0.045)\end{array}$ & & $\begin{array}{l}-0.080 * \\
(0.032)\end{array}$ & $\begin{array}{l}-0.099^{*} \\
(0.074)\end{array}$ & $\begin{array}{l}-0.118 \\
(0.108)\end{array}$ \\
\hline Sargan $P$ & 0.8613 & 0.8679 & 0.8756 & 0.8578 & 0.8713 & 0.8010 & 0.8351 & 0.7878 \\
\hline $\operatorname{AR}(1)$ & 0.0005 & 0.0006 & 0.0005 & 0.0005 & 0.0006 & 0.0006 & 0.0005 & 0.0007 \\
\hline $\mathrm{AR}(2)$ & 0.9487 & 0.9897 & 0.9397 & 0.9576 & 0.9836 & 0.9859 & 0.9627 & 0.9635 \\
\hline Num of Instruments & 16 & 17 & 17 & 17 & 18 & 18 & 18 & 19 \\
\hline Obs & 483 & 483 & 483 & 483 & 483 & 483 & 483 & 483 \\
\hline
\end{tabular}

Note $1:{ }^{*}, * * * * *$ stands for significant at the significance level of $10 \%, 5 \%$ and $1 \%$ respectively. Note 2 : the values in the table are the coefficients before the variables and the values in brackets are the standard errors.

\section{Conclusions and Policy Implications}

Through the above theoretical analysis and empirical test, we can draw a conclusion that the optimization of the financial structure is able to alleviate the financing constraints of small- and medium-sized enterprises. Moreover, the enhancement of the status of small- and medium-sized enterprises in the banking sector is the key to solving the problem. Around this conclusion, this paper summarizes from four levels, and puts forward relevant policy recommendations.

1. The promotion of the status of small- and medium-sized banks is able to significantly alleviate the financing constraints of small- and medium-sized enterprises.

Because of the basic reason of information asymmetry, small- and medium-sized enterprises are unable to obtain loans from several large state-owned commercial banks. For small- and medium-sized enterprises lacking sufficient "hard information", small- and medium-sized banks have obvious advantages in dealing with their "soft information". The small and medium sized enterprises lack the financial statements audited by the accounting firms, and they have a smaller number of mortgaged assets, while the credit evaluation mechanism of the large banks is based on the objective and quantifiable financial indicators. Therefore, it is difficult for small and medium enterprises to obtain financing. The small- and medium-sized banks have the advantage of information production, and they are able to excavate and evaluate the "soft information" which is difficult to quantify, such as the management ability of the enterprise management, the individual quality and the future of the enterprise. Furthermore, the local loans will also help to establish relationship lending, thus providing long-term financing for small- and medium-sized enterprises. The empirical research in this paper also shows that the increase in the scale ratio of small- and medium-sized banks in the banking sector is able to significantly alleviate the financing constraints of small- and medium-sized enterprises.

Therefore, China should relax the restrictions on the establishment of small- and medium-sized banks, and encourage small- and medium-sized banks to set up branches, and allow them to break the original regional restrictions so that they can develop in other provinces, thus promoting the scale of small- and medium-sized banks to expand continuously. Specifically, we can focus on some local industrial parks, incubators, the introduction of small and medium banks and their cooperation to provide loans to help small- and medium-sized banks expand their scale and maintain long-term stable 
business relations. The Securities Regulatory Commission, the Banking and Insurance Regulatory Commission, the Fund Industry Association, and so on, can encourage financial institutions such as securities, funds, insurance, trusts, and other financial institutions to develop business relations with small- and medium-sized banks. This will help small- and medium-sized banks to obtain more capital and customer resources, faster expansion of the scale.

2. The importance of small- and medium-sized banks reflects the importance of the banking structure.

The promotion of the status of small- and medium-sized banks is able to solve the financing difficulties for the small- and medium-sized enterprises. But at present, the scale proportion of small- and medium-sized banks to the banking sector is less than $50 \%$ in most provinces and cities in China, while that of the small- and medium-sized banks in the United States is more than $75 \%$. The unreasonable scale structure of China's banking industry has directly hindered the financing of small- and medium-sized enterprises, and seriously affected the allocation efficiency of financial resources. Credit funds from the banking system are China's main financing channels and a large amount of funds are allocated through banks to all regions and industries. The banking sector is the center of national currency circulation, interest rate adjustment and investment and financing, and banks play a crucial role in the allocation of funds, mobilization of savings and risk diversification. The difficulty of financing for small- and medium-sized enterprises shows that whether the banking structure can allocate funds to the most efficient areas and industries will have an important impact on the economic growth and development of the region and industry. The local finance in China tends to hinder banks from providing financing for enterprises, so the efficiency of resource allocation is reduced, and the effect of the optimization in the banking structure cannot be fully reflected. In particular, the financing sources of enterprises in some provinces and cities, especially in the western region, are local finance, large state-owned banks and local small- and medium-sized banks in turn. Therefore, it can be seen that the financial sector provides financing for enterprises while hindering the role of the financial system.

Therefore, we should gradually weaken the role of local finance in enterprise financing, create more space for the development of small- and medium-sized banks in financing and strengthen the role of the financial market in terms of the allocation of funds, so as to promote the balanced development of the economy in all regions. At the same time, the China Banking Regulatory Commission may appropriately introduce some policies to protect small- and medium-sized banks and supervise the monopoly of large banks and local financial allocations, so as to create a good market environment for the development of small- and medium-sized enterprises.

3. The reform of financial structure dominated by the banking sector is the priority of the current reform.

The current stage of economic development and the level of national income determine that the Chinese financial system is dominated by the banking industry, and the irrational banking structure directly hinders the investment and financing of enterprises and the development of the real economy. Therefore, in the critical period of economic restructuring, there is an urgent need to solve the problem of irrational banking structure. China's labor resources are relatively abundant. This factor endowment structure determines that the labor-intensive industries dominated by small- and medium-sized enterprises are the fundamental characteristics of China's industrial structure. And then, the financial structure should adapt to the characteristics of the industrial structure, and provide financing services for small- and medium-sized enterprises in an effective way, so as to achieve the optimal match between the financial sector and the real economy. The current financial reform is in full swing, and the promotion of the interest rate market, the construction of the multi-level capital market, the prevention and control of the financial risk and the supervision of the financial system are all the key points for the future reform. However, we cannot ignore the challenges that the financial structure is faced with, since the five state-owned commercial banks are in the monopoly position in the banking industry, while the small and medium sized banks, which are the source of financing for small- and medium-sized enterprises, have lagged behind. In the case of irrational financial structure, 
the expansion of the scale of the financial market is only on the surface, while it is unable to support the development of the real economy effectively. The empirical test in this paper also indicates that the expansion of the scale of the banking sector and the stock market is unable to significantly alleviate the financing constraints of the small- and medium-sized enterprises.

As a result, it is a breakthrough point for the current financial reform to break the monopoly of large banks and to promote the development of small- and medium-sized banks, so that we should relax the restrictions of private capital entering the capital market of small and medium banks, inject more financial resources for small- and medium-sized banks, and promote the structural reform of the banking industry. Specifically, we can appropriately liberalize the restrictions on equity investment, help small- and medium-sized banks cooperate with PE (Private Equity) and VC (Venture Capital), set up venture capital funds for small- and medium-sized enterprises, and provide financial support for small- and medium-sized enterprises through equity debt financing. In addition, in policy terms, small- and medium-sized banks can be encouraged to develop supply chain finance operations, leading the core enterprises of the supply chain to small- and medium-sized banks, thus creating synergies. It can not only break the credit monopoly of large banks, but also help small and medium banks to establish long-term credit relationship.

4. Although the small- and medium-sized banks are able to assist in the financing of the smalland medium-sized enterprises, their own risk management cannot be ignored.

While creating favorable external conditions for the development of small- and medium-sized banks, we should not ignore their internal governance. Small- and medium-sized banks are not as well capitalized as big banks, and they have a relatively short operating life. Therefore, they lack experience in credit evaluation system and risk management. Moreover, the small- and medium-sized enterprises generally lack detailed financial statement information and perfect internal control, so that small- and medium-sized banks have relatively high difficulties and risks in granting of loans.

Thus, we should improve the credit system of small and medium banks, standardize the financing behavior of small- and medium-sized enterprises, and reduce the risk of breach of contract through a complete guarantee and legislative system, in order to assist the small- and medium-sized banks in maintaining a long-term lending relationship with the small- and medium-sized enterprises. Specifically, it is possible to allow small- and medium-sized banks to communicate with local industrial and commercial systems and tax authorities in order to obtain information about small- and medium-sized enterprises. It helps small and medium banks to analyze the technical level, industrial chain, and operating condition of these enterprises, and to evaluate credit risk more accurately. In the bank, the Banking Regulatory Commission should urge the small and medium banks to improve their due diligence, risk assessment, and early warning, after the follow-up and other links of the process and personnel, to promote the establishment of a perfect risk management and internal control.

After drawing the above conclusions and putting forward some relevant suggestions, there are still some shortcomings in this paper, which may be the future research direction: (1) this paper studies the financing difficulties of Small and Micro enterprises from the perspective of the overall financial structure, but there may be some differences in the financial structure among different regions. Future research can consider regional differences, understand the current situation of Small and Micro enterprises financing difficulties in various regions, and then put forward some more targeted suggestions to promote the balanced development of interregional economy. (2) In the study of financing constraints of small- and medium-sized enterprises, the influencing factors are enterprise itself and financial factors, but social factors have not been considered. The future research may consider the influence of some factors such as the small- and medium-sized enterprise social service, the local human resources, and the population structure. (3) On the financing of small- and medium-sized enterprises, some supporting policies have been issued at present. The implementation effect of relevant financing support policies can be studied in the future, and some adjustment ideas and modest efforts can be contributed to the reform. 
Author Contributions: Guangyou Zhou performed the theory analysis and contributed to drafting this manuscript. Sumei Luo conceived and empirical analysis. Yuxi Zhang analyzed the data. The authors share equal contribution.

Acknowledgments: The research for this paper was supported by the National Natural Science Foundation of China (No. 71573050; No. 71573170) and the Shanghai Social Science Fund (No. 2015BJB003).

Conflicts of Interest: The authors declare no conflict of interest.

\section{References}

1. Al-Zoubi, H.A.; O'Sullivan, J.A.; Alwathnani, A.M. Business cycles, financial cycles and capital structure. Ann. Financ. 2018, 1, 105-123. [CrossRef]

2. John, R.G.; Mark, T.L.; Michael, R.R. A Century of Capital Structure: The Leveraging of Corporate America. J. Financ. Econ. 2015, 3, 658-683.

3. Castellani, D. Mortgage-backed Securitization and SME Lending during the Financial and Economic Crisis: Evidence from the Italian Cooperative Banking System. Econ. Notes 2018, 1, 187-221. [CrossRef]

4. Zarutskie, R. Competition, Financial Innovation and Commercial Bank Loan Portfolios. J. Financ. Int. 2013, 3, 373-396. [CrossRef]

5. Farruggio, C.; Uhde, A. Determinants of Loan Securitization in European Banking. J. Bank. Financ. 2015, 56, 12-27. [CrossRef]

6. Hoffmann, M.; Bent, E.S. Small Firms and Domestic Bank Dependence in Europe's Great Recession; Working Paper; University of Zurich: Zurich, Switzerland, 2015.

7. Almazan, A.; De Motta, A.; Titman, S. Debt, Labor Markets and the Creation and Destruction of Firms. J. Financ. Econ. 2015, 3, 636-657. [CrossRef]

8. Chodorow-Reich, G. The Employment Effects of Credit Market Disruptions: Firm-level Evidence from the 2008-9 Financial Crisis. Q. J. Econ. 2014, 1, 1-59. [CrossRef]

9. Fogel, K.; Morck, R.; Yeung, B. Big Businedd Stability and Economic Growth: Is What's Good for General Motors Good for America? J. Financ. Econ. 2008, 89, 83-108. [CrossRef]

10. Myers, S.C. The Capital Structure Puzzle. J. Financ. 1984, 3, 575-592. [CrossRef]

11. Myers, S.C. Still Searching for Optimal Capital Structure. J. Appl. Corp. Financ. 1993, 6, 4-14. [CrossRef]

12. Jiang, L.; Liu, X. Research on Economic Cyclical Fluctuation and Cash Holding Behavior of Listed Companies. Account. Res. 2011, 9, 40-46.

13. Zhang, H.; Lu, Z. The Cash Distribution, the Corporate Governance and the Over-investment: An Investigation Based on the State of the Cash Holdings of China's Listed Companies and their Subsidiaries. Manag. World 2012, 3, 141-150.

14. Huang, W.; Mazouz, K. Excess Cash, Trading Continuity, and Liquidity Risk. J. Corp. Financ. 2018, 48, 275-291. [CrossRef]

15. Cole, R.A. What Do We Know about the Capital Structure of Privately Held US Firms? Evidence from the Surveys of Small Business Finance. Financ. Manag. 2013, 4, 777-813. [CrossRef]

16. Cai, J.; Sun, D.; Li, H. Marketization of Interest Rate and Financing Constraints of Enterprises: An Empirical Analysis Based on the Enterprise Data in Beijing. Shanghai Financ. 2015, 11, 3-11.

17. Hadlock, C.J.; Pierce, J.R. New evidence on measuring financial constraints: Moving beyond the KZ index. Rev. Financ. Stud. 2010, 5, 1909-1940. [CrossRef]

18. Ylhäinen, I. Life-cycle effects in small business finance. J. Bank. Financ. 2017, 77, 176-196. [CrossRef]

19. Kieschnick, R.; Moussawi, R. Firm age, Corporate Governance and Capital Structure Choices. J. Corp. Financ. 2018, 48, 597-614. [CrossRef]

20. Hasan, M.M. Organization Capital and Firm Life Cycle. J. Corp. Financ. 2018, 48, 556-578. [CrossRef]

21. Munir, Q.; Kok, S.C.; Teplova, T.; Li, T. Powerful CEOs, debt financing, and leasing in Chinese SMEs: Evidence from threshold model. N. Am. J. Econ. Financ. 2017, 42, 487-503. [CrossRef]

22. Shibata, T.; Nishihara, M. Investment Timing, Reversibility and Financing Constraints. J. Corp. Financ. 2018, 48, 771-796. [CrossRef]

23. Poncet, S.; Steingress, W.; Vandenbussche, H. Financial constraints in China: Firm-level evidence. China Econ. Rev. 2010, 3, 411-422. [CrossRef] 
24. Dong, Y.; Men, C. SME Financing in Emerging Markets: Firm Characteristics, Banking Structure and Institutions. Emerg. Mark. Financ. Trade 2014, 1, 120-149. [CrossRef]

25. Martellini, L.; Milhau, V.; Tarelli, A. Capital Structure Decisions and the Optimal Design of Corporate Market Debt Prograams. J. Corp. Financ. 2018, 167, 141-167. [CrossRef]

26. Wang, D.J.; Zhang, X.J. Research on Interest Rate Marketization, Enterprise Financing and Financial Institutions' Credit Behavior. J. World Econ. 2007, 2, 50-60.

27. Ranciere, R.; Tornell, A.; Westermann, F. Decomposing the Effects of Financial Liberalization. J. Bank. Financ. 2006, 30, 3331-3348. [CrossRef]

28. Jiang, F.; Jiang, Z.; Kim, K.A. Capital markets, financial institutions, and corporate finance in China. J. Corp. Financ. 2017. [CrossRef]

29. Li, D.; Liang, Y.; Dong, Z.; Dai, Z. Analysis of Financing Problems for the Small- and medium-sized Enterprises in China under the Condition of Interest Rate Marketization. Shanghai Financ. 2017, 12, 10-17.

30. Tang, J.; Chen, D. Financial Development and Financing Constraints: Evidence from Listed SMEs. Financ. Trade Econ. 2009, 5, 5-11.

31. Brown, J.R.; Martinsson, G.; Petersen, B.C. Do Financing Constraints Matter for RandD? Eur. Econ. Rev. 2012, 8, 1512-1529. [CrossRef]

32. Van der Schans, D. The British Business Bank's role in facilitating economic growth by addressing imperfections in SME finance markets. Venture Cap. 2015, 17, 7-25. [CrossRef]

33. Zhang, Q.; Chen, R. Application of metabolic GM $(1,1)$ model in financial repression approach to the financing difficulty of the small- and medium-sized enterprises. Grey Syst. Theory Appl. 2014, 2, 311-320. [CrossRef]

34. Li, J.; Hu, F. Financing Structure, and Financing Cost of SMEs, and the Development of the Shadow Credit Market in China. Macroeconomics 2013, 5, 7-11.

35. Feng, X.; Moon, L.; Ryu, K. Supply Chain Coordination under Budget Constraints. Comput. Ind. Eng. 2015, 88, 487-500. [CrossRef]

36. Carbo-Valverde, S.; Rodriguez-Fernandez, F.; Udell, G.F. Trade Credit. The Financial Crisis, and SME Access to Finance. J. Money Credit Banking 2016, 1, 113-143. [CrossRef]

37. Leon, F. Does Bank Competition Alleviate Credit Constraints in Developing Countries? J. Bank. Financ. 2015, 8, 130-142. [CrossRef]

38. Love, I.; Peria, M.S.M. How Bank Competition Affects Firms' Access to Finance. World Bank Econ. Rev. 2015, 3, 413-448. [CrossRef]

39. Ryan, R.M.; O'Toole, C.M.; McCann, F. Does bank market power affect SME financing constraints? J. Bank. Financ. 2014, 12, 495-505. [CrossRef]

40. Demirg-Kunt, A.; Feyen, E.; Levine, R. The Evolving Importance of Banks and Securities Markets. World Bank Econ. Rev. 2013, 3, 476-490. [CrossRef]

41. Mercieca, S.; Schaeck, K.; Wolfe, S. Bank Market Structure, Competition, and SME Financing Relationships in European Regions. J. Financ. Serv. Res. 2009, 36, 137. [CrossRef]

42. Chong, T.T.L.; Lu, L.; Ongena, S. Does Banking Competition Alleviate or Worsen Credit Constraints Faced by Small- and medium-sized Enterprises? Evidence from China. J. Bank. Financ. 2013, 9, 3412-3424. [CrossRef]

43. Quaye, I.; Abrokwah, E.; Sarbah, A.; Osei, J.Y. Bridging the SME Financing Gap in Ghana: The Role of Microfinance Institutions. Open J. Bus. Manag. 2014, 4, 339-353. [CrossRef]

44. Berger, A.N.; Black, L.K. Black. Bank size, lending technologies and small business finance. J. Bank. Financ. 2010, 3, 724-735.

45. Uchida, H.; Udell, G.F.; Yamori, N. Loan Officers and Relationship Lending to SMEs. J. Financ. Int. 2011, 1, 97-122. [CrossRef]

46. Yao, Y.; Dong, G. Financial Development Level vs. Financial Structure: Which Is More Important for Easing Financing Constraints of SMEs? Evidence from China's Companies Listed on SME Board. J. Financ. Res. 2015, 4, 148-161.

47. De la Torre, A.; Peria, M.S.M.; Schmukler, S.L. Bank Involvement with SMEs: Beyond Relationship Lending. J. Bank. Financ. 2010, 9, 2280-2293. [CrossRef]

48. Lin, J.Y.; Sun, X.; Jiang, Y. Toward a Theory of Optimal Financial Structure in Economic Development. Econ. Res. J. 2009, 8, 4-17. 
49. Modigliani, F.; Miller, M.H. The Cost of Capital, Corporation Finance and the Theory of Investment. Am. Econ. Rev. 1958, 3, 261-297.

50. Fazzari, S.M.; Hubbard, R.G.; Petersen, B.C.; Blinder, A.S.; Poterba, J.M. Financing Constraints and Corporate Investment. Brook. Papers Econ. Act. 1988, 1, 141-206. [CrossRef]

51. Laven, L. Does Financial Liberalization Reduce Financing Constraints? Financ. Manag. 2003, 32, 5-34. [CrossRef]

52. Bond, S.; Meghir, C. Dynamic Investment Models and the Firm's Financial Policy. Rev. Econ. Stud. 1994, 2, 197-222. [CrossRef]

53. Chan, K.S.; Dang, V.Q.; Yan, I.K. Chinese firms' political connection, ownership and financing constraints. Econ. Lett. 2012, 11, 164-167. [CrossRef]

54. Shen, H.B.; Kou, H.; Zhang, C. An Empirical Study of Financial Development, Financing Constraints and Corporate Investment. China Ind. Econ. 2010, 6, 55-64.

C 2018 by the authors. Licensee MDPI, Basel, Switzerland. This article is an open access article distributed under the terms and conditions of the Creative Commons Attribution (CC BY) license (http:// creativecommons.org/licenses/by/4.0/). 